\title{
Synthesis, hydrolysis, biochemical and theoretical evaluation of 1,4-bis(alkoxycarbonyl)azetidin-2-ones as potential elastase inhibitors
}

\author{
Stéphane Gérard, ${ }^{\mathrm{a}}$ Georges Dive, ${ }^{\mathrm{b}}$ Brigitte Clamot, ${ }^{\mathrm{a}}$ Roland Touillaux ${ }^{\mathrm{c}}$ \\ and Jacqueline Marchand-Brynaert ${ }^{\mathrm{a}, *}$ \\ ${ }^{a}$ Unité de Chimie Organique et Médicinale, Université Catholique de Louvain, Bâtiment Lavoisier, Place Louis Pasteur 1, \\ B-1348 Louvain-la-Neuve, Belgium \\ ${ }^{\mathrm{b}}$ Centre d'Ingénierie des Protéines, Université de Liège, Bâtiment B6, allée de la chimie 17, B-4000 Sart-Tilman, Liege, Belgium \\ ${ }^{\mathrm{c}}$ Unité d'Analyse Structurale, Université Catholique de Louvain, Bâtiment Lavoisier, Place Louis Pasteur 1, \\ B-1348 Louvain-la-Neuve, Belgium
}

Received 11 September 2001; revised 20 December 2001; accepted 24 January 2002

\begin{abstract}
A series of 1,4-bis(alkoxycarbonyl)azetidin-2-ones, designed as potential suicide-inhibitors of serine proteases, has been synthesized and evaluated against porcine pancreatic elastase (PPE). The most active compound $\left(K_{\mathrm{i}} \sim 10 \mu \mathrm{M}\right.$; reversible inhibitor) was equipped with phenethyloxycarbonyl and benzyloxycarbonyl side-chains at positions $\mathrm{N} 1$ and $\mathrm{C} 4$, respectively, with the $(S)$-configuration. ${ }^{1} \mathrm{H}$ NMR spectroscopic analysis of the reaction mixtures showed that the ester function is preferentially hydrolyzed, in both chemical and enzyme-catalyzed reactions, with regard to the azetidinone and urethane functions. Considering the three potentially sensitive carbonyl functions and the two stereoisomers, ab initio calculations were performed to determine the energetic barriers required to reach the transition state structures of hydrolysis in a model of the enzyme pocket. (C) 2002 Elsevier Science Ltd. All rights reserved.
\end{abstract}

\section{Introduction}

The search for mechanism-based inhibitors ${ }^{1}$ of serine proteases is still an attractive approach for the discovery of new active compounds. Important target-enzymes are $\beta$-lactamases ${ }^{2}$ and DD-transpeptidases ${ }^{3}$ for antibacterial drugs, and elastases ${ }^{4}$ for anti-inflammatory drugs. Various reactive chemical structures have been considered to interact with the essential serine nucleophile of the enzymic cavity, as for instance, $\alpha$-fluoroketones, ${ }^{5}$ halo-enollactones, ${ }^{6}$ benzisothiazolones, ${ }^{7}$ phthalimides, ${ }^{8}$ thiadiazolidinones, ${ }^{9}$ and coumarinic derivatives. ${ }^{10,11}$ However, the $\beta$-lactam heterocycle (azetidin-2-one) remains one of the most exploited lead-structures, ${ }^{12-14}$ due to the remarkable activity of the naturally occurring antibiotics (penicillins and cephalosporins) which are bicyclic azetidinones. ${ }^{15}$ Monocyclic azetidinones also behave as serine-protease inhibitors, provided that they are adequately functionalized with substituents raising specific enzyme recognition and chemical activation towards nucleophilic attack. ${ }^{16}$ Moreover, the presence of a potential leaving group could

\footnotetext{
Keywords: $\beta$-lactam; serine-protease inhibition; elastase; ab initio calculation.

* Corresponding author. Tel.: +32-10-47-27-40; fax: +32-10-47-41-68; e-mail: marchand@chim.ucl.ac.be
}

promote irreversible inhibition via a suicide-type mechanism. ${ }^{17-22}$

Recently, we became interested in the development of new $\beta$-lactamic inhibitors bearing both the activating substituent (EWG: electron-withdrawing group) and the leaving group (LG) in position N1. ${ }^{23} \mathrm{~A}$ first combination of EWG and LG substituents resulted in the synthesis of $N$-[ $\alpha$-(heterofunctionalized)-carboxymethylated]-azetidinones which could unmask a reactive Schiff base under processing by the target-enzymes. However, the compounds tested were found to be inactive against $\beta$-lactamases of classes A, B, C, and $\mathrm{D}$, and to behave as weak reversible inhibitors of porcine pancreatic elastase (PPE). ${ }^{23}$ Another series of azetidinones (general structure A) was equipped with $\mathrm{N}$-(alkoxycarbonyl) substituents designed to unmask an isocyanate function ${ }^{24}$ into the enzymic cavity, by ring opening under nucleophilic attack of Ser-195 followed by expulsion of the alkoxyl group; suicide-inhibition was expected by quenching of the isocyanate intermediate with a nucleophilic residue (His-57), as illustrated in Scheme 1. Only a few studies of activated ( $\mathrm{N}$-acyl or $\mathrm{N}$-sulfonyl) carbamate hydrolysis have been described in the literature ${ }^{25}$ however, formation of electrophilic intermediates (isocyanates) over a wide $\mathrm{pH}$ range has been unambiguously proved by kinetics and trapping experiments. In this chemical process, the quality of the leaving group appears important; it could be 


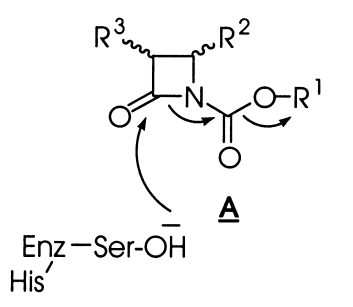<smiles>[R]OC(C)C</smiles>

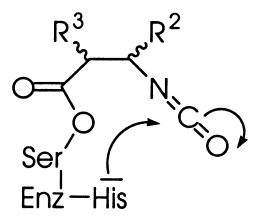

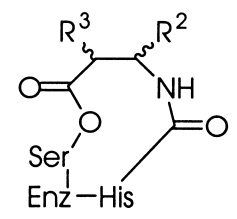<smiles>CCO</smiles><smiles>[R3]C(C(=O)O)[C@@H]([R2])NC(=O)[13CH][R16](=O)O</smiles>

Scheme 1. Expected mechanism of suicide-inhibition of serine proteases.

of less significance in an enzymic process where proton transfer and specific interaction with the protein occur. Experimentally, we found that 3-bromo-derivatives $\underline{\mathrm{A}}$ $\left(\mathrm{R}^{3}=(R)-\mathrm{Br} ; \mathrm{R}^{2}=\mathrm{H} ; \mathrm{R}^{1}=\mathrm{CH}_{2} \mathrm{Ph}, \mathrm{CH}_{2} \mathrm{CCl}_{3}, \mathrm{CH}_{2} \mathrm{CF}_{3}\right)$ were transient inhibitors of PPE (low $k_{\text {cat }}$ and $K_{\mathrm{m}}$ values); the enzyme catalyzes ring opening, but without expulsion of the leaving group. ${ }^{26}$

With a view to improving the biological activity of the $N$-(alkoxycarbonyl)azetidinones towards elastase, we considered new derivatives bearing a side chain in position $\mathrm{C} 4$, combining enzymic recognition and activation factors, namely an alkyloxycarbonyl group. Such an electronwithdrawing substituent has been previously reported to fit well into the active site of elastases (human leukocyte elastase (HLE) and PPE) in the case of azetidinones equipped with a sulfonyl substituent, ${ }^{27}$ or a benzoyl $\operatorname{group}^{28}$ in position $\mathrm{N} 1$; enzymic hydrolysis induced the cleavage of the activated $\beta$-lactam bond. In this paper, we describe the synthesis and the hydrolysis (chemical and enzymic) of azetidinones $\mathrm{A}$ bearing alkoxycarbonyl substituents in both positions $\overline{\mathrm{N}} 1$ and $\mathrm{C} 4$. Unexpected results stimulated a theoretical study of reactivity.

\section{Results and discussion}

\subsection{Synthesis}

$N$-Acyl-azetidinones could be prepared from $N$-unsubstituted precursors by deprotonation with lithium hexamethyldisilazide at low temperature and quenching of the resulting anion with chloroformates. ${ }^{26}$ This procedure has been applied to the synthesis of compounds 3-9 (Scheme 2, Table 1), starting from the commercially available azetidinone $\mathbf{1}$ and azetidinone $\mathbf{2}$ obtained in four steps from aspartic acid $[(S)$-enantiomer or racemic mixture $]{ }^{29,30}$ The chloroformates (except benzylchloroformate) were prepared by reacting the corresponding alcohols, namely phenethyl alcohol, 3-phenylpropyl alcohol, 2-indanol and 2-cyclohexylethanol, with triphosgene and pyridine in toluene at $0{ }^{\circ} \mathrm{C}{ }^{31}$ The $N$-substituted derivatives 3-9 were purified by chromatography on silica gel, and were characterized by NMR spectroscopy. The 4-substituted azetidinones 5-9 showed a typical ABX pattern for the $\mathrm{H} 4, \mathrm{H} 3$

and $\mathrm{H}^{\prime}{ }^{\prime}$ protons at $4.45 \delta\left(\mathrm{dd}, \quad J_{\text {cis }}=6.6 \mathrm{~Hz}\right.$ and $\left.J_{\text {trans }}=3.3 \mathrm{~Hz}\right), 3.30 \delta\left(\mathrm{dd}, J_{\mathrm{AB}}=15.9\right.$ and $\left.6.6 \mathrm{~Hz}\right)$ and 3.00 $\delta\left(\mathrm{dd}, J_{\mathrm{AB}}=15.9\right.$ and $\left.3.3 \mathrm{~Hz}\right)$, respectively. The three carbonylic carbons appeared at $168.6 \delta$ (ester), $161.7 \delta$ ( $\beta$-lactam) and $147.9 \delta$ (carbamate). The $\beta$-lactam carbonyl stretching at $1812 \mathrm{~cm}^{-1}$ for compounds $\mathbf{3 , 4}$ shifted to $1825 \mathrm{~cm}^{-1}$ for compounds 5-9 bearing the ester substituent (electron-withdrawing substituent at $\mathrm{C} 4$ ).

Enantiomerically pure azetidinone 6a was obtained starting from 2a $[(S)$-enantiomer], while $\mathbf{6 b}[(R)$-enantiomer] was isolated by preparative HPLC of racemic $\mathbf{6}$ over a chiral stationary phase.

Compounds 10a (methyl ester) and 11a ( $i$-propyl ester) (Scheme 3), prepared by transesterification ${ }^{32}$ of $\mathbf{2 a}$, were $\mathrm{N}$-functionalized with the phenethyloxycarbonyl sidechain as above; the NMR spectroscopic features of the

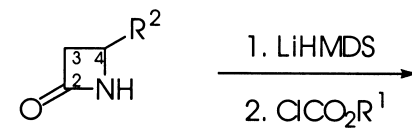

$1, \mathrm{R}^{2}=\mathrm{H}$

2a $R^{2}=\mathrm{CO}_{2} \mathrm{CH}_{2} \mathrm{Ph}(\mathrm{S})$

2b, $\mathrm{R}^{2}=\mathrm{CO}_{2} \mathrm{CH}_{2} \mathrm{Ph}(\mathrm{R})$

Scheme 2. Synthesis of compounds.

Table 1. Yields of compounds

\begin{tabular}{lcllc}
\hline Entry & Compound & \multicolumn{1}{c}{$\mathrm{R}^{2}$} & \multicolumn{1}{c}{$\mathrm{R}^{1}$} & Yield $^{\mathrm{a}}(\%)$ \\
\hline 1 & $\mathbf{3}$ & $\mathrm{H}$ & $\mathrm{CH}_{2} \mathrm{Ph}$ & 75 \\
2 & $\mathbf{4}$ & $\mathrm{H}$ & $\mathrm{CH}_{2} \mathrm{CH}_{2} \mathrm{Ph}$ & 98 \\
3 & $\mathbf{5}^{\mathrm{b}}$ & $\mathrm{CO}_{2} \mathrm{CH}_{2} \mathrm{Ph}$ & $\mathrm{CH}_{2} \mathrm{Ph}$ & 68 \\
4 & $\mathbf{6}^{\mathrm{b}}$ & $\mathrm{CO}_{2} \mathrm{CH}_{2} \mathrm{Ph}$ & $\mathrm{CH}_{2} \mathrm{CH}_{2} \mathrm{Ph}$ & 50 \\
5 & $7^{\mathrm{b}}$ & $\mathrm{CO}_{2} \mathrm{CH}_{2} \mathrm{Ph}$ & $\mathrm{CH}_{2} \mathrm{CH}_{2} \mathrm{CH}_{2} \mathrm{Ph}$ & 75 \\
6 & $\mathbf{8}^{\mathrm{b}}$ & $\mathrm{CO}_{2} \mathrm{CH}_{2} \mathrm{Ph}$ & \\
7 & $\mathbf{9}^{\mathrm{b}}$ & $\mathrm{CO}_{2} \mathrm{CH}_{2} \mathrm{Ph}$ & $\mathrm{CH}_{2} \mathrm{CH}_{2}$ & 56 \\
\hline
\end{tabular}

a Isolated by column-chromatography.

${ }^{b}$ Racemic mixture. 


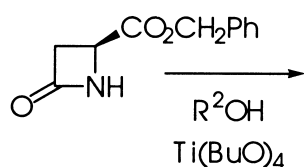<smiles>O=C1CC(C(=O)O)N1</smiles><smiles>O=C(Cl)CCc1ccccc1</smiles>

Ref 32

$2 a$
$10 a R^{2}=M e$ $11 a R^{2}=i P r$<smiles>[R20]C1CC(=O)N1C(=O)OCCc1ccccc1</smiles>

$12 a R^{2}=\operatorname{Me}(50 \%)$

$13 a R^{2}=i \operatorname{Pr}(76 \%)$

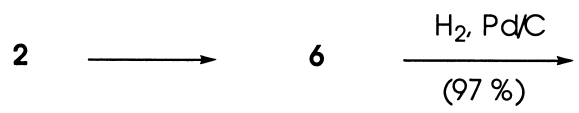<smiles>O=C(O)C1CC(=O)N1C(=O)OCCc1ccccc1</smiles>

14

Scheme 3. Synthesis of compounds.

resulting azetidinone 12a $[(S)$-enantiomer $]$ and 13a $[(S)$ enantiomer] were similar to those of $\mathbf{6}$. Lastly, the free acid 14 (Scheme 3) resulted from hydrogenolysis of the benzyl ester $\mathbf{6}$.

\subsection{Elastase inhibition}

Compounds 2-14 were evaluated for their potential inhibitory effect on PPE. This readily available enzyme could be considered as a good model of HLE; crystallographic studies have demonstrated ${ }^{33}$ the structural similarity between the active sites of both enzymes.

The rates of elastase-catalyzed hydrolysis of $N$-succinylAla-Ala-Ala- $p$-nitroanilide (substrate) were measured $\left([\mathrm{E}]=2 \times 10^{-7} \mathrm{M} ;[\mathrm{S}]=3 \times 10^{-4} \mathrm{M}, \mathrm{pH} 7.5\right)$ in the presence of various concentrations of potential inhibitors $\left([\mathrm{I}]=10^{-4}\right.$, $5 \times 10^{-5}$ and $\left.10^{-5} \mathrm{M}\right)$. The variation of absorbance at $410 \mathrm{~nm}$ was recorded as a function of time (Fig. 1A); transient inhibitions were observed, then complete enzymic activity was restored after about $180 \mathrm{~min}$. The control of the reversibility was assessed as usual by the incubation\ dilution method (see Section 4).

Plots of $V / V_{\mathrm{I}}$, corresponding to the ratios of initial rates of hydrolysis in the absence and in the presence of inhibitor versus the concentration of inhibitor gave a straight line where the slope corresponds to $1 / K_{\mathrm{i}}$. The measured inhibition constants $\left(K_{\mathrm{i}}\right)$ are collected in Table 2.

Table 2. PPE inhibition

\begin{tabular}{|c|c|c|c|c|}
\hline Compound & $\mathrm{R}^{1}$ & $\mathrm{R}^{2}$ & $\mathrm{R}^{3}$ & $K_{\mathrm{i}}(\mu \mathrm{M})$ \\
\hline 2 & - & $\mathrm{CO}_{2} \mathrm{CH}_{2} \mathrm{Ph}$ & $\mathrm{H}$ & No inhibition \\
\hline 3 & $\mathrm{CH}_{2} \mathrm{Ph}$ & $\mathrm{H}$ & $\mathrm{H}$ & No inhibition \\
\hline 4 & $\mathrm{CH}_{2} \mathrm{CH}_{2} \mathrm{Ph}$ & $\mathrm{H}$ & $\mathrm{H}$ & Low $\left(>10^{3}\right)$ \\
\hline 5 & $\mathrm{CH}_{2} \mathrm{Ph}$ & $\mathrm{CO}_{2} \mathrm{CH}_{2} \mathrm{Ph}$ & $\mathrm{H}$ & 110 \\
\hline 6 & $\mathrm{CH}_{2} \mathrm{CH}_{2} \mathrm{Ph}$ & $\mathrm{CO}_{2} \mathrm{CH}_{2} \mathrm{Ph}$ & $\mathrm{H}$ & 12 \\
\hline $\mathbf{6 a}(S)$ & $\mathrm{CH}_{2} \mathrm{CH}_{2} \mathrm{Ph}$ & $\mathrm{CO}_{2} \mathrm{CH}_{2} \mathrm{Ph}$ & $\mathrm{H}$ & 10 \\
\hline $\mathbf{6 b}(R)$ & $\mathrm{CH}_{2} \mathrm{CH}_{2} \mathrm{Ph}$ & $\mathrm{CO}_{2} \mathrm{CH}_{2} \mathrm{Ph}$ & $\mathrm{H}$ & 330 \\
\hline 7 & $\mathrm{CH}_{2} \mathrm{CH}_{2} \mathrm{CH}_{2} \mathrm{Ph}$ & $\mathrm{CO}_{2} \mathrm{CH}_{2} \mathrm{Ph}$ & $\mathrm{H}$ & 50 \\
\hline 8 & & $\mathrm{CO}_{2} \mathrm{CH}_{2} \mathrm{Ph}$ & $\mathrm{H}$ & No inhibition \\
\hline 9 & $\mathrm{CH}_{2} \mathrm{CH}_{2} \simeq$ & $\mathrm{CO}_{2} \mathrm{CH}_{2} \mathrm{Ph}$ & $\mathrm{H}$ & No inhibition \\
\hline 12a $(S)$ & $\mathrm{CH}_{2} \mathrm{CH}_{2} \mathrm{Ph}$ & $\mathrm{CO}_{2} \mathrm{CH}_{3}$ & $\mathrm{H}$ & 68 \\
\hline 13a $(S)$ & $\mathrm{CH}_{2} \mathrm{CH}_{2} \mathrm{Ph}$ & $\mathrm{CO}_{2} \mathrm{CH}\left(\mathrm{CH}_{3}\right)_{2}$ & $\mathrm{H}$ & 87 \\
\hline 14 & $\mathrm{CH}_{2} \mathrm{CH}_{2} \mathrm{Ph}$ & $\mathrm{CO}_{2} \mathrm{H}$ & $\mathrm{H}$ & $\geq 700$ \\
\hline 15 & $\mathrm{CH}_{2} \mathrm{Ph}$ & $\mathrm{H}$ & $\mathrm{Br}$ & 1.5 \\
\hline
\end{tabular}

See Scheme 1 for $\mathrm{R}^{1} / \mathrm{R}^{2} / \mathrm{R}^{3}$ description.

The presence of the N1-alkoxycarbonyl substituent is required for activity, since 2 was inactive. However, a second alkoxycarbonyl substituent at $\mathrm{C} 4$ dramatically

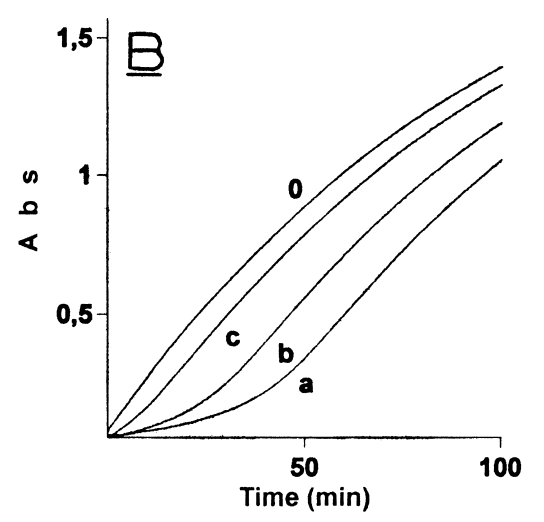

Figure 1. Inhibition of PPE by compound 6a $(A)\left(0,[I]=0 ; a,[I]=10^{-4} \mathrm{M} ; \mathrm{b},[\mathrm{I}]=5 \times 10^{-5} \mathrm{M}\right.$ and $\left.\mathrm{c},[\mathrm{I}]=10^{-5} \mathrm{M}\right)$ and compound $15(\underline{B})(0,[\mathrm{I}]=0$; a, $[\mathrm{I}]=10^{-4} \mathrm{M} ; \mathrm{b},[\mathrm{I}]=5 \times 10^{-5} \mathrm{M}$ and $\left.\mathrm{c},[\mathrm{I}]=10^{-5} \overline{\mathrm{M}}\right)$. 
improved the inhibitory effect, as shown by comparison of $\mathbf{3}$ and 4 to, respectively, 5 and 6 . Evaluation of each enantiomer of $\mathbf{6}$ revealed that the activity is mainly due to the $(S)$-enantiomer 6a giving a $K_{\mathrm{i}}$ value of $10 \mu \mathrm{M}$. This enantioselectivity is opposite to that observed with related C4-substituted inhibitors (such as Merck's L-694,458), ${ }^{34}$ and could suggest a different positioning in the active site. Also, the best enzymic fit required the presence of a phenyl residue on the $\mathrm{R}^{1}$ side-chain (compare 6 with 9) with a twomethylene spacer (compare $\mathbf{6}$ with $\mathbf{5}$ and 7), and some flexibility (compare $\mathbf{6}$ with $\mathbf{8}$ ). Replacing the benzyl ester of the $\mathrm{R}^{2}$ side-chain with methyl or isopropyl esters did not greatly reduce the inhibitory activity (compare 6 with 12 and 13), while the corresponding free carboxylate $\mathbf{1 4}$ was found to be practically inactive. Thus, by varying the $\mathrm{N} 1$ and $\mathrm{C} 4$ sidechains, we could not find a better inhibitor than $6 \mathbf{a}$. However, this compound remained about 10 times less active than the 3-bromo-azetidinone $\mathbf{1 5}$ (Table 2) described previously. ${ }^{26}$ Moreover, the inhibition curves of 6 (Fig. 1A), and related $\mathrm{C} 4$ substituted compounds $(\mathbf{5}, \mathbf{7}, \mathbf{1 2}, \mathbf{1 3})$ displayed a totally different shape compared to the reference 15 (Fig. 1B), suggesting a different mode of action. It has been demonstrated by NMR spectroscopic experiments that the $\beta$-lactam ring of compound $\mathbf{1 5}$ was easily opened by chemical or enzymic hydrolysis, but without expulsion of $\mathrm{R}^{1} \mathrm{OH}$. The reactions of $\mathbf{4}$ and $\mathbf{6}$ were similarly monitored by ${ }^{1} \mathrm{H}$ NMR spectroscopy.

\subsection{NMR spectroscopic study}

A solution of $\beta$-lactam $4\left(10^{-3} \mathrm{M}\right)$ in deuteriated phosphate buffer $\left(\mathrm{pD} 7.5 ; 50 \mathrm{mM}\right.$ ) containing $5 \%$ of DMSO-d $\mathrm{d}_{6}$ was

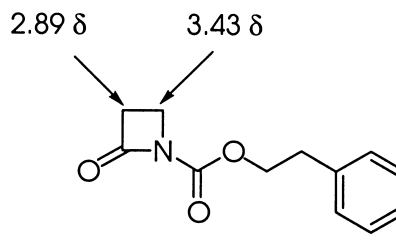

4 analyzed by ${ }^{1} \mathrm{H}$ NMR spectroscopy at $500 \mathrm{MHz}$ as a function of time. No detectable reaction occurred within $24 \mathrm{~h}$. Addition of PPE $\left(6 \times 10^{-5} \mathrm{M}\right)$ led to the slow transformation of 4 into $\beta$-aminoacid derivative 16 (Scheme 4); the $\beta$-lactam ring opening was ascertained by the significant deshielding of the former's C3 and C4 protons. As in the case of compound 15, no cleavage of the urethane function was observed. This is consistent with the kinetic measurements, and the curve shapes (recorded by spectrophotometry) of $\mathbf{4}$ which look like to those of $\mathbf{1 5}$.

The inhibitor 6 behaved totally different. In the absence of enzyme, chemical hydrolysis slowly occurred $\left(10^{-3} \mathrm{M}\right.$ solution of 6 in deuteriated phosphate buffer, $\mathrm{pD} 7.5$, $50 \mathrm{mM}+5 \%$ DMSO-d 6 ), leading to the acid 14 (Scheme 5) as a result of ester cleavage without $\beta$-lactam ring opening; benzyl alcohol was formed (singlet at $4.44 \delta$ ), but not phenethyl alcohol (two triplets at $2.68 \delta$ and $3.65 \delta$ ). Acid 14 was unambiguously identified by comparison with a reference sample prepared by hydrogenolysis of $\mathbf{6}$.

Nucleophilic attack on activated $\beta$-lactams (N1-EWG derivatives) is a known methodology for the construction of functionalized $\beta$-aminoacid derivatives. ${ }^{35}$ However, examples involving a possible competition between azetidinone ring opening and attack on an ester substituent are not described very often. Carbon based nucleophiles (sulfone stabilized carbanions, for instance) showed low selectivity for the $\beta$-lactam carbonyl (N1-Boc or N1-Cbz derivatives) over benzyl ester, but complete selectivity towards ring opening occurred in the presence of a $t$-butyl ester. $^{36}$ Glycosyl anions, ${ }^{37}$ cyanide and azide ${ }^{38}$ exclusively

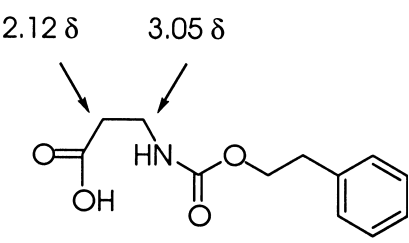

16

Scheme 4. Enzymic hydrolysis of 4.



6

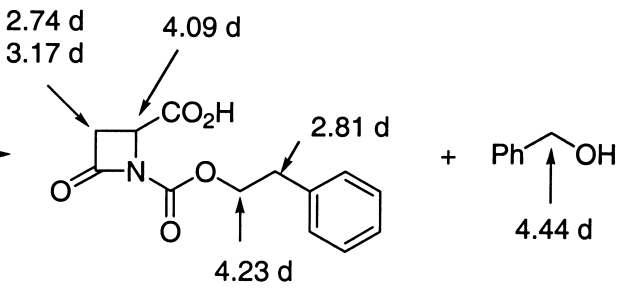

14

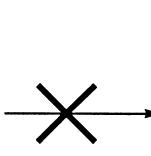<smiles>O=C=NC(CC(=O)O)C(=O)OCc1ccccc1</smiles><smiles>O=C(O)C(O)Cc1ccccc1</smiles>

Scheme 5. Chemical and enzymic hydrolysis of $6 \mathbf{a}$ 
reacted on the azetidinone, leaving benzyl or methyl ester substituents untouched. Accordingly, $\mathrm{CN}^{-}$and $\mathrm{N}_{3}{ }^{-}$were used as catalysts for the chemoselective aminolysis or alcoholysis of $\mathrm{N}$-alkoxycarbonyl azetidinones bearing a C4 ester substituent. ${ }^{38}$ As far as basic hydrolysis is concerned, one publication reported that $N$-arylsulfonylazetidinones equipped with an alkoxycarbonyl substituent at $\mathrm{C} 4$ are hydrolyzed in phosphate buffer, ${ }^{28 \mathrm{~b}}$ giving the cleavage of the $\beta$-lactam ring without ester saponification. We did not identify hydrolysis studies related to our compounds 5-13 (Schemes 2 and 3). Thus, our results show that the N1 alkoxycarbonyl substituent of $\mathbf{6}$ is not sufficiently electron-withdrawing to promote nucleophilic attack of hydroxide anion on the $\beta$-lactam carbonyl over the ester carbonyl, as it was the case with a N1 arylsulfonyl substituent.

Although another hydrolysis profile could be expected under enzyme processing, in the presence of PPE $\left(6 \times 10^{-5} \mathrm{M}\right)$, the catalyzed hydrolysis of $\mathbf{6 a}$ rapidly proceeded to the same products, i.e. acid 14a and benzyl alcohol. Products resulting from $\beta$-lactam ring opening could not be identified, nor phenethyl alcohol, as expected in the case of a suicide-type mechanism of serine-enzyme inhibition (Scheme 5). Amongst the three carbonyl groups (azetidinone, urethane and ester) of $\mathbf{6 a}$ being potentially sensitive to Ser-195 nucleophilic attack, only the ester was hydrolyzed by the enzyme. Thus, 6a (and related compounds 5, 7, 12 and 13) behaved differently from 15, and most probably were transient inhibitors via a different mode of action and fit in the enzymic cavity.

Enzyme-catalyzed hydrolysis of C4 ester groups has never been mentioned for previously reported elastase inhibitors bearing N1 arylsulfonyl or benzoyl substituents. ${ }^{27,28}$ Therefore, we turned to theoretical chemistry as a possible predictive tool in this subtle competition between the different carbonyl groups of $\underline{\mathrm{A}}$ (Scheme $1, \mathrm{R}^{2}=\mathrm{CO}_{2} \mathrm{CH}_{2} \mathrm{Ph}$ ) towards nucleophilic attack.

\subsection{Theoretical evaluation}

The reactivity of $\beta$-lactams $\mathbf{3}, \mathbf{5}, \mathbf{6}$ and $\mathbf{1 5}$, has been evaluated by theoretical methods. The mechanism of cleavage of the $\mathrm{N} 1-\mathrm{C} 2$ azetidinone bond has been extensively studied in the context of chemical stability of antibiotics and their hydrolysis by $\beta$-lactamases. ${ }^{39,40}$ In our case, we have also considered the cleavage of the $(\mathrm{O}) \mathrm{C}-\mathrm{O}$ ester bond $(5$ and 6$)$ and $(\mathrm{O}) \mathrm{C}-\mathrm{O}$ urethane bond $(\mathbf{3}, \mathbf{1 5}, \mathbf{5}$ and $\mathbf{6})$.

The catalytic environment was mimicked by an imidazole as a model of His-57, a water molecule as a transient vehicle of the proton and the side-chain of Ser-195 including the amide bond of the backbone which is involved in the stabilization of the oxyanion hole (Fig. 2). Nucleophilic



Figure 2. Model of elastase active site. attack of Ser-195 was considered from the $\alpha$ face of the azetidinone. At the transition state, the amide $\mathrm{N}-\mathrm{H}$ generates a pseudo seven-membered ring including the oxygen atom of the carbonyl ( $\beta$-lactam carbonyl as shown in Fig. 2, or ester/urethane carbonyl) and the $\gamma$-oxygen atom of the nucleophile. An analogous model has been studied to highlight the catalytic mechanism of class-A $\beta$-lactamases. ${ }^{40}$ In the trypsin family, the activation barriers thus estimated have been correlated with the free energy variation observed between native and mutated enzymes. ${ }^{1,41}$

With more than 80 atoms, the molecular system could only be handled at the ab initio level with a minimal basis set. The accuracy of the results derived from the Huzinaga basis has been demonstrated in previous studies. ${ }^{40,41}$ The $\Delta G$ values have been computed by reference to the isolated partners. The high values obtained give an indication of the complexation effort that has to be performed by the enzyme to generate the Michaelis complex as the starting point of the reaction path toward the transition state. On the other hand, the optimization of the complexes connected by the transition state could generate nonrepresentative structures as the active site geometric constraints are not taken into account in the ab initio calculations.

For compound 6, six combinations have been studied depending on the broken $\mathrm{C}-\mathrm{N} / \mathrm{C}-\mathrm{O}$ bond for the $(S)$ and $(R)$ enantiomers. The activation barrier is lower for $\mathbf{6 b}$, the molecule having the $(R)$ configuration. The $\mathrm{C}-\mathrm{N}$ transition state $\left({ }^{*}\right.$ in Table 3 ) could not be quenched as a stationary point; the highest first derivative component remains higher then the usual threshold in spite of very careful optimization runs. The given value can be seen as a lower bound of the energy involved in the $\mathrm{C}-\mathrm{N}$ cleavage.

Table 3. Calculated energies $(\mathrm{kcal} / \mathrm{mol})$ at the transition states

\begin{tabular}{|c|c|c|c|c|}
\hline Compound & Cleaved bond $^{\mathrm{a}}$ & $\Delta E$ & $\Delta H$ & $\Delta G$ \\
\hline 3 & $\mathrm{C}-\mathrm{N}$ & 17.46 & 17.94 & 40.07 \\
\hline 15 & $\mathrm{C}-\mathrm{N}$ & 14.26 & 14.73 & 36.87 \\
\hline \multirow[t]{2}{*}{$(S)-\mathbf{5 a}$} & $\mathrm{C}-\mathrm{N}$ & 17.95 & 18.44 & 40.27 \\
\hline & $\mathrm{C}-\mathrm{O} 1$ & 19.54 & 19.78 & 41.15 \\
\hline \multirow[t]{3}{*}{$(S)-\mathbf{6 a}$} & $\mathrm{C}-\mathrm{N}$ & 19.41 & 19.90 & 44.05 \\
\hline & $\mathrm{C}-\mathrm{O} 1$ & 20.78 & 21.12 & 42.79 \\
\hline & $\mathrm{C}-\mathrm{O} 2$ & 17.97 & 18.45 & 41.50 \\
\hline \multirow[t]{3}{*}{$(R)-6 \mathbf{b}$} & $\mathrm{C}-\mathrm{N}\left({ }^{*}\right)$ & 13.45 & 13.40 & 38.38 \\
\hline & $\mathrm{C}-\mathrm{O} 1$ & 16.20 & 16.43 & 40.00 \\
\hline & $\mathrm{C}-\mathrm{O} 2$ & 16.00 & 16.48 & 39.13 \\
\hline
\end{tabular}

${ }^{a} \mathrm{C}-\mathrm{N}$ azetidinone bond, $\mathrm{C}-\mathrm{O} 1$ ester bond, $\mathrm{C}-\mathrm{O} 2$ urethane bond.

The alkoxycarbonyl side-chain at $\mathrm{C} 4$ significantly increased the barrier height for compound $\mathbf{6 a}$ with the $(S)$ configuration, comparatively to its $(R)$ enantiomer $\mathbf{6 b}$, and compounds $\mathbf{3}$ and $\mathbf{1 5}$ devoid of such a side-chain. In this last case, the electronic effect of the bromine was expressed by the decrease of the energy barrier. The lower reactivity of the azetidinone function in $\mathbf{6 a}$ could result from a lack of conjugation with the N1 carbonyl substituent due to an electronic repulsion effect with the $\mathrm{C} 4$ carbonyl group at the transition state, a phenomenon which does not occur in $\mathbf{6 b}$ (Fig. 3 shows the respective diastereoisomeric transition states).

Considering the $\mathrm{C}-\mathrm{O} 1$ and the $\mathrm{C}-\mathrm{O} 2$ cleavages, the activa- 


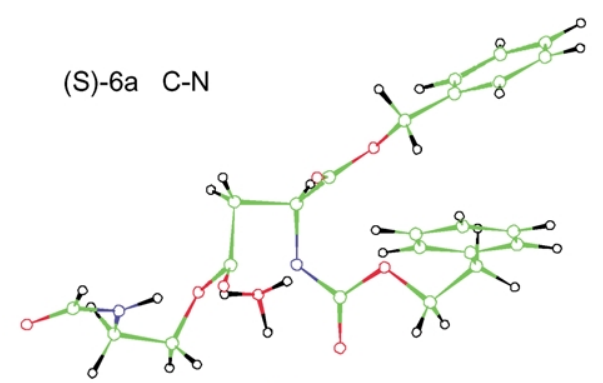

की

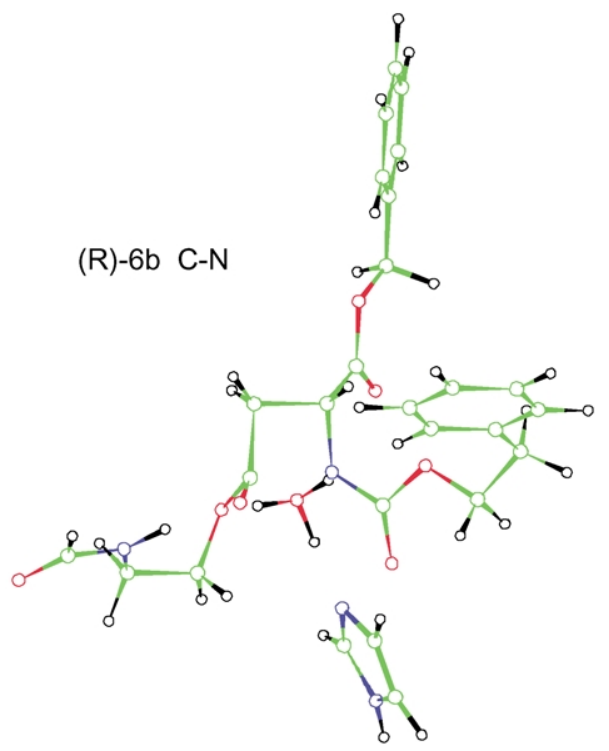

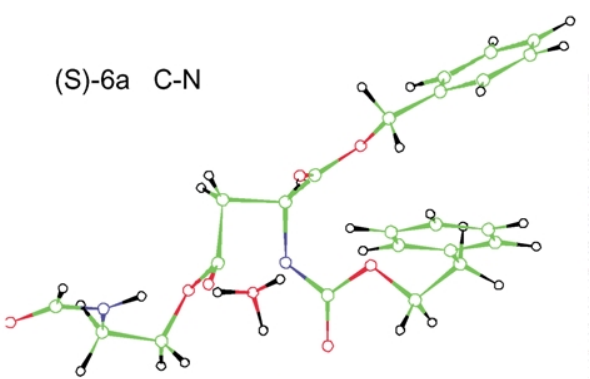

की

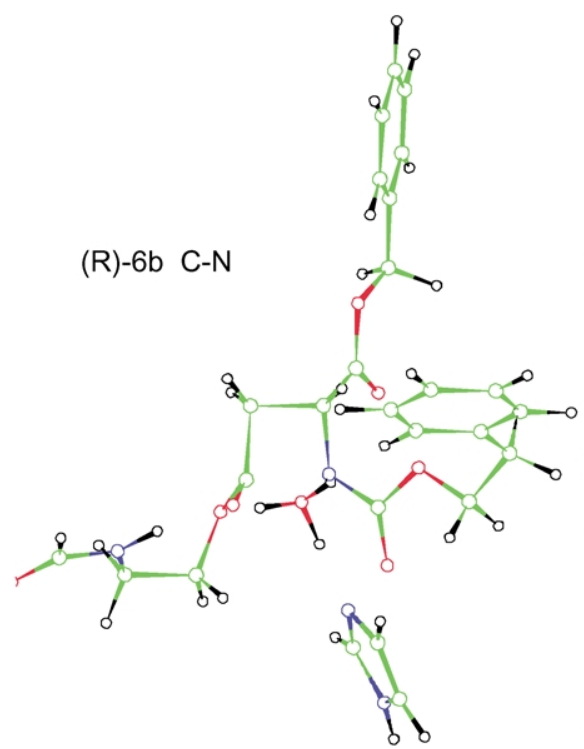

Figure 3. Stereoscopic view of the transition state of $\mathrm{C}-\mathrm{N}$ cleavage in: (a) $6 \mathbf{a}(S)$ and (b) $\mathbf{6 b}(R)$. Atom coloring: red, oxygen; blue, nitrogen; green, carbon; black, hydrogen.

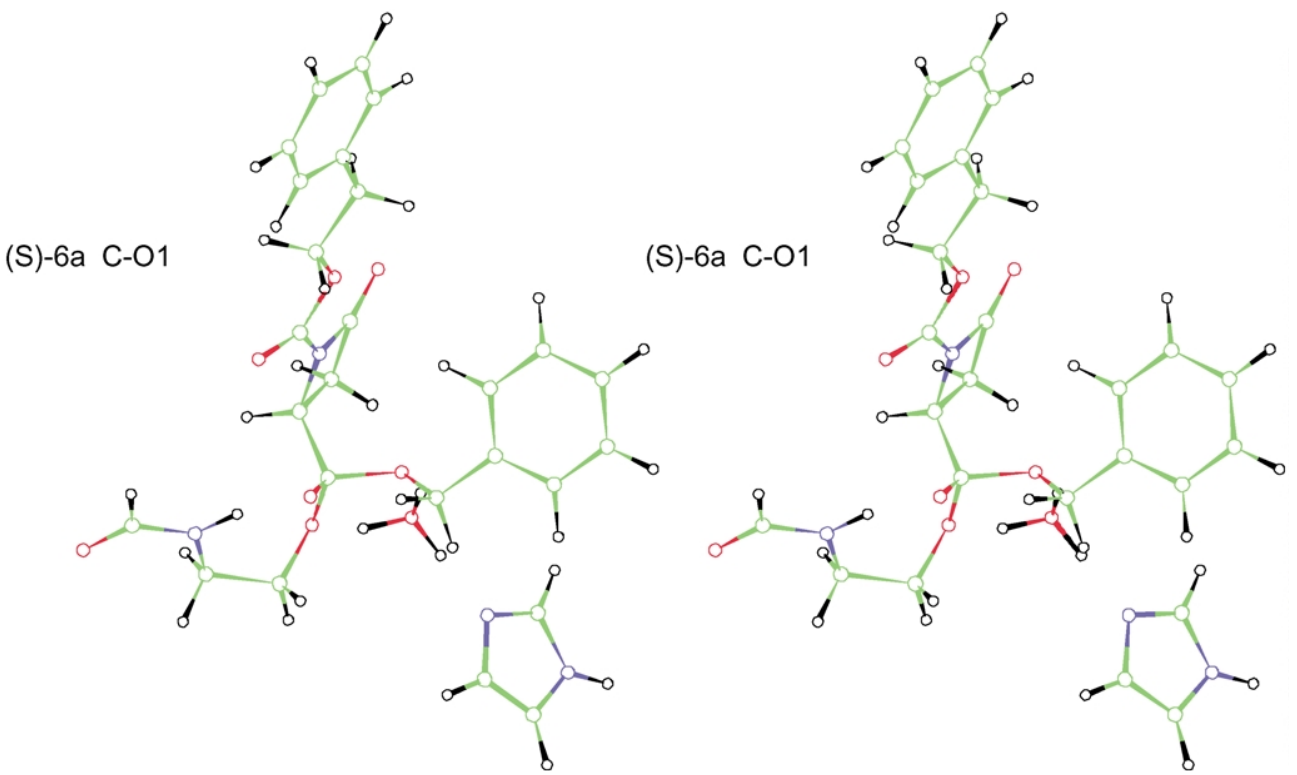

Figure 4. Stereoscopic view of the transition state of $\mathrm{C}-\mathrm{O} 1$ cleavage in $6 \mathbf{a}(S)$. Atom coloring: red, oxygen; blue, nitrogen; green, carbon; black, hydrogen. 
tion barriers are also lower for $\mathbf{6 b}$ than for $\mathbf{6 a}$. Moreover, in the active compound $\mathbf{6 a}$, the differences between $\mathrm{C}-\mathrm{N}$ and $\mathrm{C}-\mathrm{O}$ breaking processes are not very high. The three possible hydrolysis routes are energetically accessible, and therefore would depend on the best fit of the molecule into the enzymic cavity. Fig. 4 shows the transition state of the $\mathrm{C}-\mathrm{O} 1$ cleavage in $\mathbf{6 a}$, the process experimentally observed.

\section{Conclusions}

A series of monocyclic $\beta$-lactams sharing the general structure A (Scheme 1) has been prepared. They are characterized by various lipophilic $\mathrm{R}^{1}$ substituents and an alkoxycarbonyl side-chain at position $\mathrm{C} 4$. The compounds were designed to promote the suicide-inhibition of serineenzymes such as elastases. When tested against PPE, $\beta$-lactams 5-7 and 12-13 were found to be reversible inhibitors of the enzyme $\left(K_{\mathrm{i}}\right.$ of about $\left.10-100 \mu \mathrm{M}\right)$, while $\beta$-lactams 8, 9 and 14 were inactive.

NMR analysis of the crude mixtures resulting from chemical or enzymic hydrolysis of $\mathbf{6 a}$ (chosen as model for all the series of compounds $\underline{A}$ ), revealed an unexpected reaction: the $\mathrm{C} 4$ ester group was cleaved instead of the azetidinone amide bond. A similar observation has been reported occasionally in the case of one ester of 6-chloromethyl-2oxo- $2 \mathrm{H}$-1-benzopyran-3-carboxylic acid tested against HLE; the enzyme reacted with the exocyclic ester. ${ }^{42}$

Geometry optimization of compound $\mathbf{6 a}$ showed a particular conformation of the $\mathrm{N} 1$ side-chain due to the repulsion between the C5 and C6 carbonyls which occurs when C2 suffers nucleophilic attack from the $\alpha$ face. Considering the three potentially sensitive carbonyl functions (C2, C5 and C6), ab initio calculations were performed to determine the energetic barriers required to reach the transition state structures of hydrolysis in a model of enzymic cavity. The most reactive compound was the $(R)$-enantiomer of $\mathbf{6}$; but experimentally, we have demonstrated that this isomer $\mathbf{6 b}$ is not well recognized by PPE. On the other hand, the active isomer $6 \mathbf{a}$ appeared somewhat less reactive than $\mathbf{6 b}$, considering the three hydrolysis processes. Also, discrimination between the three hydrolysis processes of $\mathbf{6 a}$ could not be made from our theoretical approach. Thus, the best fit into the enzymic pocket is definitively the crucial factor determining the chemoselectivity of the substrate/inactivator hydrolysis pathway. This has been confirmed by docking experiments. ${ }^{43}$ The possibility of increasing the chemical/ enzymic reactivity of the $\beta$-lactam carbonyl $\mathrm{C} 2$ by suppressing the C5/C6 carbonyl repulsion is currently under investigation.

\section{Experimental}

\subsection{General}

Reagents and solvents were purchased from Acros chimica, Aldrich or Fluka. Porcine pancreatic elastase (type 1) and $N$-succinyl-L-alanyl-L-alanyl-L-alanyl- $p$-nitroanilide were obtained from Sigma Chemical Co. Tetrahydrofuran was dried with sodium/benzophenone, then distilled. Column chromatographies were carried out with silicagel 60 (70230 mesh ASTM) supplied by Merck. The IR spectra were recorded with a Perkin-Elmer 1710 instrument, only the most significant absorption bands being reported. The mass spectra were obtained with a Finnigan MAT TSQ-70 instrument. The microanalyses were performed at the Christopher Ingold Laboratories of the University College, London (Dr A. Stones). The melting points were determined with an Electrothermal microscope and are uncorrected. The ${ }^{1} \mathrm{H}$ and ${ }^{13} \mathrm{C}$ NMR spectra were recorded on Varian Gemini 300 (at $300 \mathrm{MHz}$ for proton and $75 \mathrm{MHz}$ for carbon) or Bruker AM-500 spectrometers (at $500 \mathrm{MHz}$ for proton and $125 \mathrm{MHz}$ for carbon); the chemical shifts are reported in ppm $(\delta)$ downfield from tetramethylsilane (internal standard) or dimethylsulfoxide.

\subsection{Synthesis, general procedure for the preparation of chloroformates}

To a cold solution (ice-bath) of triphosgene ( 0.4 equiv.) in toluene $(5 \mathrm{~mL} / \mathrm{mmol})$ was added dropwise (over $2 \mathrm{~h}$ ) pyridine (1.25 equiv.). After $1 \mathrm{~h}$ stirring at $0^{\circ} \mathrm{C}$, alcohol (1 equiv.) was added dropwise (over $30 \mathrm{~min}$ ). The mixture was stirred for $17 \mathrm{~h}$ at $20^{\circ} \mathrm{C}$, then filtered. The precipitate was rinsed twice with toluene. Concentration of the filtrate under vacuum gave crude chloroformate (about $85 \%$ yield).

4.2.1. Phenethyl chloroformate. It was obtained from $594 \mathrm{mg}(2 \mathrm{mmol})$ of triphosgene, $10 \mathrm{~mL}$ of toluene, $505 \mu \mathrm{L}(6.25 \mathrm{mmol})$ of pyridine and $597 \mu \mathrm{L}(5 \mathrm{mmol})$ of phenethyl alcohol. ${ }^{1} \mathrm{H}$ NMR $\left(200 \mathrm{MHz}, \mathrm{CDCl}_{3}\right): \delta$ 7.15$7.39(\mathrm{~m}, 5 \mathrm{H}), 4.50(\mathrm{t}, 2 \mathrm{H}, J=7 \mathrm{~Hz}), 3.02(\mathrm{t}, 2 \mathrm{H}, J=7 \mathrm{~Hz})$. ${ }^{13} \mathrm{C} \mathrm{NMR}\left(50 \mathrm{MHz}, \mathrm{CDCl}_{3}\right): \delta 150.7,136.4,129.0,128.9$, 127.2, 72.3, 34.9.

4.2.2. Phenylpropyl chloroformate. It was obtained from $594 \mathrm{mg}(2 \mathrm{mmol})$ of triphosgene, $10 \mathrm{~mL}$ of toluene, $505 \mu \mathrm{L}$ $(6.25 \mathrm{mmol})$ of pyridine and $676 \mu \mathrm{L}(5 \mathrm{mmol})$ of phenylpropyl alcohol. ${ }^{1} \mathrm{H}$ NMR $\left(200 \mathrm{MHz}, \mathrm{CDCl}_{3}\right): \delta 7.10-7.35$ $(\mathrm{m}, 5 \mathrm{H}), 4.27(\mathrm{t}, 2 \mathrm{H}, J=6.6 \mathrm{~Hz}), 2.69(\mathrm{t}, 2 \mathrm{H}, J=6.6 \mathrm{~Hz})$, 2.01 (quint, $2 \mathrm{H}, J=6.6 \mathrm{~Hz}) .{ }^{13} \mathrm{C} \mathrm{NMR}\left(50 \mathrm{MHz}, \mathrm{CDCl}_{3}\right)$ : $\delta 150.2,140.3,128.5,128.3,126.2,71.3,31.5,29.6$.

4.2.3. 2-Indanyl chloroformate. It was obtained from $476 \mathrm{mg}(1.6 \mathrm{mmol})$ of triphosgene, $9 \mathrm{~mL}$ of toluene, $401 \mu \mathrm{L}(5 \mathrm{mmol})$ of pyridine and $537 \mu \mathrm{L}(4 \mathrm{mmol})$ of 2-indanol in $3 \mathrm{~mL}$ of toluene. ${ }^{1} \mathrm{H} \mathrm{NMR}(200 \mathrm{MHz}$, $\left.\mathrm{CDCl}_{3}\right): \delta 7.25(\mathrm{~m}, 5 \mathrm{H}), 5.62(\mathrm{~m}, 1 \mathrm{H}), 3.38(\mathrm{dd}, 2 \mathrm{H}$, $J=17.4$ and $6.2 \mathrm{~Hz}), 3.18(\mathrm{dd}, 2 \mathrm{H}, J=17.4$ and $2.8 \mathrm{~Hz})$. ${ }^{13} \mathrm{C} \mathrm{NMR}\left(50 \mathrm{MHz}, \mathrm{CDCl}_{3}\right): \delta 150.2,139.1,127.0,124.5$, 83.7, 39.1.

4.2.4. Cyclohexylethyl chloroformate. It was obtained from $594 \mathrm{mg}(2 \mathrm{mmol})$ of triphosgene, $10 \mathrm{~mL}$ of toluene, $505 \mu \mathrm{L}(6.25 \mathrm{mmol})$ of pyridine and $696 \mu \mathrm{L}(5 \mathrm{mmol})$ of 2-cyclohexylethanol in $3 \mathrm{~mL}$ of toluene. ${ }^{1} \mathrm{H}$ NMR $\left(200 \mathrm{MHz}, \mathrm{CDCl}_{3}\right): \delta 4.42(\mathrm{t}, 2 \mathrm{H}, J=6.8 \mathrm{~Hz}), 1.76(\mathrm{~m}$, $2 \mathrm{H}), 1.71(\mathrm{t}, 2 \mathrm{H}, J=6.8 \mathrm{~Hz}), 1.48(\mathrm{~m}, 1 \mathrm{H}), 1.28(\mathrm{~m}, 4 \mathrm{H})$, $1.02(\mathrm{~m}, 4 \mathrm{H}) .{ }^{13} \mathrm{C} \mathrm{NMR}\left(50 \mathrm{MHz}, \mathrm{CDCl}_{3}\right): \delta 150.8,70.8$, $37.8,34.3,33.2,33.1,26.5,26.3,26.2$. 


\subsection{General procedure for 1-alkoxycarbonylazetidin-2- ones}

A solution of LiHMDS (1 equiv.) in dry THF ( $5 \mathrm{~mL} / \mathrm{mmol}$ ) was dropwise added to a solution of azetidin-2-one ( 1 equiv.) in dry $\mathrm{THF}(5 \mathrm{~mL} / \mathrm{mmol})$, cooled at $-78^{\circ} \mathrm{C}$ under argon atmosphere. The mixture was stirred for $30 \mathrm{~min}$ at $-78^{\circ} \mathrm{C}$, then chloroformate (1 equiv.) was added with a syringe through a rubber septum. Stirring was continued for $1 \mathrm{~h}$ at this temperature and the mixture was allowed to reach room temperature and stirred for $45 \mathrm{~min}$ at $20^{\circ} \mathrm{C}$. After addition of water and extraction with $\mathrm{CH}_{2} \mathrm{Cl}_{2}$, the organic layer was washed with brine, dried over $\mathrm{MgSO}_{4}$, filtered and concentrated under vacuum. The resulting $\beta$-lactam was purified by column chromatography on silica gel $\left(\mathrm{CH}_{2} \mathrm{Cl}_{2}-\mathrm{EtOAc}, 90 / 10\right.$ to $\left.70 / 30\right)$.

4.3.1. 1-Benzyloxycarbonylazetidin-2-one (3). This compound was obtained from $1(106 \mathrm{mg}, 1.5 \mathrm{mmol})$ by treatment with $362 \mathrm{mg}$ of LiHMDS (1.5 mmol) and $214 \mu \mathrm{L}$ of benzyl chloroformate $(1.5 \mathrm{mmol})$ to yield 3 (224 mg, 75\%) as a white solid. Mp $72-73^{\circ} \mathrm{C}$. Found: C, 64.54; $\mathrm{H}, 5.45 ; \mathrm{N}, 6.63 \% . \mathrm{C}_{11} \mathrm{H}_{11} \mathrm{O}_{3} \mathrm{~N}$ requires $\mathrm{C}, 64.38 ; \mathrm{H}$, $5.40 ; \mathrm{N}, 6.82 \%$. IR (KBr): $3054,1812,1726 \mathrm{~cm}^{-1} .{ }^{1} \mathrm{H}$ NMR $\left(300 \mathrm{MHz}, \mathrm{CDCl}_{3}\right): \delta 7.34-7.41(\mathrm{~m}, 5 \mathrm{H}), 5.27(\mathrm{~s}, 2 \mathrm{H}), 3.62$ $(\mathrm{t}, 2 \mathrm{H}, J=5.3 \mathrm{~Hz}), 3.04(\mathrm{t}, 2 \mathrm{H}, J=5.3 \mathrm{~Hz}),{ }^{13} \mathrm{C} \mathrm{NMR}$ $\left(75 \mathrm{MHz}, \mathrm{CDCl}_{3}\right): \delta$ 164.1 (CO azetidinone), $148.9(\mathrm{CO}$ carbamate), 135.1, 128.6, 128.5, 128.3, 67.9, 37.8, 36.6. MS (CI) m/z $206(\mathrm{M}+1), 107,91$.

4.3.2. 1-Phenethyloxycarbonylazetidin-2-one (4). This compound was obtained from 1 (106 mg, $1.5 \mathrm{mmol})$ by treatment with $362 \mathrm{mg}$ of LiHMDS (1.5 mmol) and $280 \mathrm{mg}$ of phenethyl chloroformate $(1.5 \mathrm{mmol})$ to yield 4 $(315 \mathrm{mg}, 98 \%)$ as a white solid. $\mathrm{Mp} 64-65^{\circ} \mathrm{C}$. Found: $\mathrm{C}$, $66.06 ; \mathrm{H}, 6.24 ; \mathrm{N}, 5.94 \% . \mathrm{C}_{12} \mathrm{H}_{13} \mathrm{O}_{3} \mathrm{~N}$ requires $\mathrm{C}, 65.74 ; \mathrm{H}$, 5.98; N, 6.38\%. IR (KBr): 2958, $1813,1729 \mathrm{~cm}^{-1} .{ }^{1} \mathrm{H}$ NMR $\left(300 \mathrm{MHz}, \mathrm{CDCl}_{3}\right): \delta 7.34-7.41(\mathrm{~m}, 5 \mathrm{H}), 4.41(\mathrm{t}, 2 \mathrm{H}$, $J=7.2 \mathrm{~Hz}), 3.58 \quad(\mathrm{t}, \quad 2 \mathrm{H}, \quad J=5.2 \mathrm{~Hz}), 3.04 \quad(\mathrm{t}, \quad 2 \mathrm{H}$, $J=5.2 \mathrm{~Hz}), 3.02(\mathrm{t}, 2 \mathrm{H}, J=7.2 \mathrm{~Hz}) .{ }^{13} \mathrm{C} \mathrm{NMR}(75 \mathrm{MHz}$, $\mathrm{CDCl}_{3}$ ): $\delta 163.8$ (CO azetidinone), 148.5 (CO carbamate), 136.8, 128.6, 128.1, 126.2, 66.4, 37.4, 36.1, 34.7. MS (CI) $\mathrm{m} / \mathrm{z} 220(\mathrm{M}+1), 114,105,70$.

4.3.3. 1-Benzyloxycarbonyl-(4-benzyloxycarbonyl)-azetidin-2-one (5). This compound was obtained from 2 (205 mg, $1 \mathrm{mmol}$ ) by treatment with $241 \mathrm{mg}$ of LiHMDS ( $1 \mathrm{mmol}$ ) and $143 \mu \mathrm{L}$ of benzyl chloroformate $(1 \mathrm{mmol})$ to yield $5(218 \mathrm{mg}, 68 \%)$ as a white solid. Mp $73-74^{\circ} \mathrm{C}$. Found: C, 67.29; $\mathrm{H}, 4.96 ; \mathrm{N}, 4.08 \% . \mathrm{C}_{19} \mathrm{H}_{17} \mathrm{O}_{5} \mathrm{~N}$ requires $\mathrm{C}, 67.25 ; \mathrm{H}, 5.05 ; \mathrm{N}, 4.13 \%$. IR (KBr): 2958, 1826, $1737 \mathrm{~cm}^{-1} .{ }^{1} \mathrm{H}$ NMR $\left(300 \mathrm{MHz}, \mathrm{CDCl}_{3}\right): \delta 7.23-7.39(\mathrm{~m}$, $10 \mathrm{H}), 5.24(\mathrm{~s}, 2 \mathrm{H}), 5.20(\mathrm{~s}, 2 \mathrm{H}), 4.48(\mathrm{dd}, 1 \mathrm{H}, J=6.6$, $3.3 \mathrm{~Hz}), 3.31(\mathrm{dd}, 1 \mathrm{H}, J=15.9,6.6 \mathrm{~Hz}), 3.03(\mathrm{dd}, 1 \mathrm{H}$, $J=15.9,3.3 \mathrm{~Hz}) .{ }^{13} \mathrm{C} \mathrm{NMR}\left(75 \mathrm{MHz}, \mathrm{CDCl}_{3}\right): \delta 168.7$ (CO ester), 161.7 (CO azetidinone), 147.9 (CO carbamate), 134.6, 128.5, 128.2, 128.1, 68.2, 67.5, 49.2 (C-4), 41.6 (C-3). MS (CI) m/z 340 (M+1), 206, 181, 107, 91.

4.3.4. 1-Phenethyloxycarbonyl-(4-benzyloxycarbonyl)azetidin-2-one (6). This compound was obtained from 2 (205 mg, $1 \mathrm{mmol}$ ) by treatment with $241 \mathrm{mg}$ of LiHMDS ( $1 \mathrm{mmol})$ and $190 \mathrm{mg}$ of phenethyl chloroformate $(1 \mathrm{mmol})$ to yield 6 (177 $\mathrm{mg}, 50 \%)$ as a white solid. $\mathrm{Mp} 100-101^{\circ} \mathrm{C}$. Found: C, 67.79; H, 5.39; N, 3.84\%. $\mathrm{C}_{20} \mathrm{H}_{19} \mathrm{O}_{5} \mathrm{~N}$ requires $\mathrm{C}$, 67.98; H, 5.42; N, 3.96\%. IR (KBr): 2965, 1823, $1732 \mathrm{~cm}^{-1}$. ${ }^{1} \mathrm{H}$ NMR $\left(300 \mathrm{MHz}, \mathrm{CDCl}_{3}\right): \delta 7.18-7.40(\mathrm{~m}, 10 \mathrm{H}), 5.20$ $(\mathrm{AB}, 2 \mathrm{H}, J=12.2 \mathrm{~Hz}), 4.43(\mathrm{dd}, 1 \mathrm{H}, J=6.6,3.3 \mathrm{~Hz}), 4.37(\mathrm{t}$, $1 \mathrm{H}, J=7.2 \mathrm{~Hz}), 4.36(\mathrm{t}, 1 \mathrm{H}, J=7.2 \mathrm{~Hz}), 3.29(\mathrm{dd}, 1 \mathrm{H}$, $J=15.9,6.6 \mathrm{~Hz}), 3.01(\mathrm{dd}, 1 \mathrm{H}, J=15.9,3.3 \mathrm{~Hz}), 2.93(\mathrm{t}$, $1 \mathrm{H}, \quad J=7.2 \mathrm{~Hz}), \quad 2.92(\mathrm{t}, \quad 1 \mathrm{H}, \quad J=7.2 \mathrm{~Hz}) .{ }^{13} \mathrm{C} \quad \mathrm{NMR}$ $\left(75 \mathrm{MHz}, \mathrm{CDCl}_{3}\right): \delta 168.6$ (CO ester), 161.7 (CO azetidinone), 147.9 (CO carbamate), 136.8, 134.6, 128.6, 128.4, 128.3, 68.2, 67.5, 67.3, 49.2 (C-4), 41.6 (C-3), 34.7. MS (CI) $\mathrm{m} / \mathrm{z} 354(\mathrm{M}+1), 262,204,135,122,105,91 .(S)$-Enantiomer $\mathbf{6 a}$ was similarly prepared from $\mathbf{2 a}:^{29,30}[\alpha]_{\mathrm{D}}{ }^{25}=-55.9$ $\left(c=0.086, \mathrm{CHCl}_{3}\right)$.

$(R)$-Enantiomer $\mathbf{6 b}$ was recovered by preparative HPLC of the racemic mixture with a chiralpak $\mathrm{AD}^{@}$ column and elution with hexane-isopropanol (90:10) at $1 \mathrm{~mL} / \mathrm{min}$; retention times were 21.1 and $23.8 \mathrm{~min}$ for the $(R)$ and the $(S)$ enantiomers, respectively; $[\alpha]_{\mathrm{D}}{ }^{25}=+38.5 \quad(c=0.500$, $\left.\mathrm{CHCl}_{3}\right)$.

4.3.5. 1-Phenylpropyloxycarbonyl-(4-benzyloxycarbonyl)azetidin-2-one (7). This compound was obtained from 2 (205 mg, $1 \mathrm{mmol}$ ) by treatment with $241 \mathrm{mg}$ of LiHMDS (1 mmol) and $198 \mathrm{mg}$ of phenylpropyl chloroformate (1 mmol) to yield $7(275 \mathrm{mg}, 75 \%)$ as a yellow oil. Found: $\mathrm{C}, 68.79 ; \mathrm{H}, 5.84 ; \mathrm{N}, 3.81 \% . \mathrm{C}_{21} \mathrm{H}_{21} \mathrm{O}_{5} \mathrm{~N}$ requires C, 68.65; H, 5.76; N, 3.81\%. IR (film): 2987, 1824, $1736 \mathrm{~cm}^{-1} .{ }^{1} \mathrm{H}$ NMR $\left(300 \mathrm{MHz}, \mathrm{CDCl}_{3}\right): \delta 7.09-7.39(\mathrm{~m}$, $10 \mathrm{H}), 5.23(\mathrm{AB}, 2 \mathrm{H}, J=12.3 \mathrm{~Hz}), 4.45(\mathrm{dd}, 1 \mathrm{H}, J=6.6$, $3.3 \mathrm{~Hz}), 4.21(\mathrm{t}, 2 \mathrm{H}, J=6.6 \mathrm{~Hz}), 3.31(\mathrm{dd}, 1 \mathrm{H}, J=15.9$, $6.6 \mathrm{~Hz}), 3.02(\mathrm{dd}, 1 \mathrm{H}, J=15.9 \mathrm{~Hz}, 3.3 \mathrm{~Hz}), 2.67(\mathrm{t}, 2 \mathrm{H}$, $J=7.2 \mathrm{~Hz}), 1.97(\mathrm{q}, 2 \mathrm{H}, J=7.2 \mathrm{~Hz}) .{ }^{13} \mathrm{C} \mathrm{NMR}(75 \mathrm{MHz}$, $\left.\mathrm{CDCl}_{3}\right): \delta 168.6$ (CO ester), 161.7 (CO azetidinone), 147.9 (CO carbamate), 140.6, 134.6, 128.5, 128.2, 125.9, 67.4, 65.9, 49.3 (C-4), 41.5 (C-3), 31.5, 29.8. MS (EI) $\mathrm{m} / \mathrm{z}$ $368(\mathrm{M}+1), 149,118,91$.

4.3.6. 1-Indanyloxycarbonyl-(4-benzyloxycarbonyl)azetidin-2-one (8). This compound was obtained from 2 (205 mg; $1 \mathrm{mmol}$ ) by treatment with $241 \mathrm{mg}$ of LiHMDS (1 mmol) and $196 \mathrm{mg}$ of indanyl chloroformate $(1 \mathrm{mmol})$ to yield 8 (204 mg, 56\%) as a yellow solid. Mp $100-101^{\circ} \mathrm{C}$. Found: $\mathrm{C}, 69.26 ; \mathrm{H}, 5.37 ; \mathrm{N}, 3.61 \% . \mathrm{C}_{21} \mathrm{H}_{19} \mathrm{O}_{5} \mathrm{~N}$ requires $\mathrm{C}$, 69.03; H, 5.24; N, 3.83\%. IR (KBr): 2959, $1823,1732 \mathrm{~cm}^{-1}$. ${ }^{1} \mathrm{H}$ NMR $\left(300 \mathrm{MHz}, \mathrm{CDCl}_{3}\right): \delta 7.15-7.41(\mathrm{~m}, 9 \mathrm{H}), 5.53(\mathrm{~m}$, $1 \mathrm{H}, J=3.3 \mathrm{~Hz}), 5.08(\mathrm{AB}, 2 \mathrm{H}, J=12.0 \mathrm{~Hz}), 4.42(\mathrm{dd}, 1 \mathrm{H}$, $J=6.6,3.3 \mathrm{~Hz}), 3.34(\mathrm{dd}, 1 \mathrm{H}, J=15.0,6.6 \mathrm{~Hz}), 3.28(\mathrm{dd}, 2 \mathrm{H}$, $J=17.0,6.6 \mathrm{~Hz}), 3.03(\mathrm{t}, 1 \mathrm{H}, J=17.0 \mathrm{~Hz}), 3.02(\mathrm{t}, 1 \mathrm{H}$, $J=17.0 \mathrm{~Hz}), 2.98(\mathrm{dd}, 1 \mathrm{H}, J=15.0 \mathrm{~Hz}, 3.3 \mathrm{~Hz}) .{ }^{13} \mathrm{C} \mathrm{NMR}$ $\left(75 \mathrm{MHz}, \mathrm{CDCl}_{3}\right)$ : $\delta 168.7$ (CO ester), 161.7 (CO azetidinone), 147.8 (CO carbamate), 139.7, 134.6, 128.5, 128.2, 128.1, 126.8, 124.6, 78.2, 67.6, 49.6 (C-4), 41.7 (C-3), 39.3. MS (CI) $m / z, 366(\mathrm{M}+1), 274,133,117,91$.

4.3.7. 1-Cyclohexylethyloxycarbonyl-(4-benzyloxycarbonyl)-azetidin-2-one (9). This compound was obtained from 2 (205 mg; $1 \mathrm{mmol})$ by treatment with $241 \mathrm{mg}$ of LiHMDS (1 mmol) and $190 \mathrm{mg}$ of cyclohexyl chloroformate $(1 \mathrm{mmol})$ to yield $9(246 \mathrm{mg}, 69 \%)$ as an oil. Found: C, 67.29; H, 7.05; N, 3.70\%. $\mathrm{C}_{20} \mathrm{H}_{25} \mathrm{O}_{5} \mathrm{~N}$ requires C, 66.83; H, 7.01; N, 3.89\%. IR (film): 2947, 1826, 
$1733 \mathrm{~cm}^{-1} .{ }^{1} \mathrm{H}$ NMR $\left(300 \mathrm{MHz}, \mathrm{CDCl}_{3}\right): \delta 7.27-7.49(\mathrm{~m}$, $5 \mathrm{H}), 5.24(\mathrm{AB}, 2 \mathrm{H}, J=12.0 \mathrm{~Hz}), 4.48(\mathrm{dd}, 1 \mathrm{H}, J=6.6$, $3.3 \mathrm{~Hz}), 4.24(\mathrm{t}, 1 \mathrm{H}, J=7.2 \mathrm{~Hz}), 4.23(\mathrm{t}, 1 \mathrm{H}, J=6.9 \mathrm{~Hz})$, $3.31(\mathrm{dd}, 1 \mathrm{H}, J=15.9,6.6 \mathrm{~Hz}), 3.02(\mathrm{dd}, 1 \mathrm{H}, J=15.9$, $3.3 \mathrm{~Hz}), 1.44-1.76(\mathrm{~m}, 7 \mathrm{H}), 1.33(\mathrm{~m}, 2 \mathrm{H}), 1.23(\mathrm{~m}, 2 \mathrm{H})$, $0.91(\mathrm{~m}, 2 \mathrm{H}) .{ }^{13} \mathrm{C} \mathrm{NMR}\left(75 \mathrm{MHz}, \mathrm{CDCl}_{3}\right): \delta 168.6(\mathrm{CO}$ ester), 161.5 (CO azetidinone), 147.9 (CO carbamate), $134.5,128.3,128.2,128.1,68.2,67.2,65.1,49.1$ (C-4), 41.3 (C-3), 35.4, 34.0, 32.7, 26.1, 25.8. MS (CI) m/z 360 $(\mathrm{M}+1), 268,111,91$.

4.3.8. 1-Phenethyloxycarbonyl-(4-methyloxycarbonyl)azetidin-2-one (12a). This compound was obtained from $\mathbf{1 0 a}^{32}(205 \mathrm{mg}, 1 \mathrm{mmol})$ by treatment with $241 \mathrm{mg}$ of LiHMDS (1 mmol) and $190 \mathrm{mg}$ of phenethylchloroformate (1 mmol) to yield 12a $(177 \mathrm{mg}, 50 \%)$ as a white solid. Mp $100-101^{\circ} \mathrm{C}$. Found: C, 60.64; H, 5.45; N, 5.05\%. $\mathrm{C}_{14} \mathrm{H}_{15} \mathrm{O}_{5} \mathrm{~N}$ requires $\mathrm{C}, 61.68 ; \mathrm{H}, 5.75 ; \mathrm{N}, 4.78 \%$. $[\alpha]_{\mathrm{D}}{ }^{25}=-45.5\left(c=1.22, \mathrm{CHCl}_{3}\right)$. IR $(\mathrm{KBr}): 2965,1823$, $1732 \mathrm{~cm}^{-1} .{ }^{1} \mathrm{H}$ NMR $\left(300 \mathrm{MHz}, \mathrm{CDCl}_{3}\right): \delta 7.15-7.38(\mathrm{~m}$, $5 \mathrm{H}), 4.43(\mathrm{dd}, 1 \mathrm{H}, J=6.6,3.3 \mathrm{~Hz}), 4.33(\mathrm{t}, 1 \mathrm{H}, J=7.2 \mathrm{~Hz})$, $4.36(\mathrm{t}, 1 \mathrm{H}, J=7.2 \mathrm{~Hz}), 3.78(\mathrm{~s}, 3 \mathrm{H}), 3.31(\mathrm{dd}, 1 \mathrm{H}, J=15.9$, $6.5 \mathrm{~Hz}), 3.05(\mathrm{dd}, 1 \mathrm{H}, J=15.9,3.3 \mathrm{~Hz}), 2.93(\mathrm{t}, 1 \mathrm{H}$, $J=7.2 \mathrm{~Hz}), 2.92(\mathrm{t}, 1 \mathrm{H}, J=7.2 \mathrm{~Hz}) .{ }^{13} \mathrm{C}$ NMR $(75 \mathrm{MHz}$, $\left.\mathrm{CDCl}_{3}\right): \delta 168.6$ (CO ester), 161.7 (CO azetidinone), 147.9 (CO carbamate), 136.8, 134.6, 128.6, 128.4, 128.3, 68.2, 67.5, 67.3, 49.2 (C-4), 41.6 (C-3), 34.7. MS (CI) $\mathrm{m} / \mathrm{z}$ $354(\mathrm{M}+1), 262,204,135,122,105,91$.

4.3.9. 1-Phenethyloxycarbonyl-(4-isopropyloxycarbonyl)azetidin-2-one (13a). This compound was obtained from $11 \mathbf{a}^{32}(113 \mathrm{mg}, 0.72 \mathrm{mmol})$ by treatment with $174 \mathrm{mg}$ of LiHMDS $(0.72 \mathrm{mmol})$ and $135 \mathrm{mg}$ of phenethyl chloroformate $(0.72 \mathrm{mmol})$ to yield $13 \mathbf{a}(167 \mathrm{mg}, 76 \%)$ as an oil. Found: C, 62.94; $\mathrm{H}, 6.27 ; \mathrm{N}, 4.58 \% . \mathrm{C}_{16} \mathrm{H}_{19} \mathrm{O}_{5} \mathrm{~N}$ requires $\mathrm{C}, 62.87 ; \mathrm{H}, 6.42 ; \mathrm{N}, 4.42 \% .[\alpha]_{\mathrm{D}}{ }^{25}=-46.4$ $\left(c=0.78, \mathrm{CHCl}_{3}\right)$. IR (film): 2976, 1825, $1732 \mathrm{~cm}^{-1} \cdot{ }^{1} \mathrm{H}$ NMR $\left(300 \mathrm{MHz}, \mathrm{CDCl}_{3}\right): \delta 7.18-7.40(\mathrm{~m}, 5 \mathrm{H}), 5.11$ (sext, 1H, $J=6.0 \mathrm{~Hz}), 4.37(\mathrm{dd}, 1 \mathrm{H}, J=6.7,3.4 \mathrm{~Hz}), 4.42$ $(\mathrm{t}, 2 \mathrm{H}, J=7.1 \mathrm{~Hz}), 4.36(\mathrm{t}, 1 \mathrm{H}, J=7.2 \mathrm{~Hz}), 3.31(\mathrm{dd}, 1 \mathrm{H}$, $J=15.6,6.7 \mathrm{~Hz}), 3.03(\mathrm{dd}, 1 \mathrm{H}, J=15.6,3.4 \mathrm{~Hz}), 3.01(\mathrm{t}$, $2 \mathrm{H}, J=7.1 \mathrm{~Hz}), 1.36(\mathrm{~d}, 3 \mathrm{H}, J=6.0 \mathrm{~Hz}), 1.32(\mathrm{~d}, 3 \mathrm{H}$, $J=6.0 \mathrm{~Hz}) .{ }^{13} \mathrm{C}$ NMR $\left(75 \mathrm{MHz}, \mathrm{CDCl}_{3}\right): \delta 168.4(\mathrm{CO}$ ester), 161.7 (CO azetidinone), 148.5 (CO carbamate), 138.2, 129.0, 128.9, 128.6, 69.9, 67.4, 49.6 (C-4), 41.6 (C-3), 34.9, 21.5. MS (CI) $m / z 306(\mathrm{M}+1), 105$, $91,86$.

\subsubsection{1-Phenethyloxycarbonyl-(4-hydroxycarbonyl)-} azetidin-2-one (14). This compound was obtained by hydrogenation in Parr apparatus $\left(12 \mathrm{~h}\right.$ under $\left.30 \mathrm{psi}, 20^{\circ} \mathrm{C}\right)$ of $6(90 \mathrm{mg}, 0.25 \mathrm{mmol})$, in solution in AcOEt $(10 \mathrm{~mL})$ with $12 \mathrm{mg}$ of $\mathrm{Pd} / \mathrm{C}$ (50 mg/mmol), to yield $14(65 \mathrm{mg}, 97 \%)$ as a white solid. Mp $104-105^{\circ} \mathrm{C}$. Found: C, 58.95; H, 5.29; N, $4.99 \% . \mathrm{C}_{13} \mathrm{H}_{13} \mathrm{O}_{5} \mathrm{~N}$ requires $\mathrm{C}, 59.31 ; \mathrm{H}, 4.98 ; \mathrm{N}, 5.32 \%$. IR (film): $3550,1815,1734 \mathrm{~cm}^{-1} .{ }^{1} \mathrm{H}$ NMR $(300 \mathrm{MHz}$, $\left.\mathrm{CDCl}_{3}\right): \delta 10.25(\mathrm{sl}, 1 \mathrm{H}), 7.18-7.40(\mathrm{~m}, 5 \mathrm{H}), 4.38(\mathrm{~m}$, $3 \mathrm{H}), 3.31(\mathrm{dd}, 1 \mathrm{H}, J=15.6,6.7 \mathrm{~Hz}), 3.06$ (dd, $1 \mathrm{H}, J=15.6$, $3.4 \mathrm{~Hz}), 2.97(\mathrm{t}, 2 \mathrm{H}, J=7.1 \mathrm{~Hz}) .{ }^{13} \mathrm{C}$ NMR $(75 \mathrm{MHz}$, $\mathrm{CDCl}_{3}$ ): $\delta 173.3$ (CO acid), 162.2 (CO azetidinone), 148.5 (CO carbamate), 136.9, 129.0, 128.9, 128.7, 67.8, 49.6 (C-4), 41.9 (C-3), 35.1. MS (CI) $m / z 262$ (M-1), 172, 105,91 .

\subsection{NMR spectroscopic study}

Chemical hydrolysis. $2 \cdot 10^{-2} \mathrm{M}$ solutions of $\mathbf{4}$ and $\mathbf{6}$ in DMSO-d $_{6}$ were added to phosphate buffer in $\mathrm{D}_{2} \mathrm{O}$ $\left(\mathrm{pD}=7.5\right.$; final concentration $\left.10^{-3} \mathrm{M}\right) .{ }^{1} \mathrm{H}$ NMR spectra $(500 \mathrm{MHz})$ were recorded every $60 \mathrm{~min} ; 4$ was not hydrolyzed, while about $50 \%$ of $\mathbf{6}$ was hydrolyzed within $36 \mathrm{~h}$.

Enzymic hydrolysis. $2 \cdot 10^{-2} \mathrm{M}$ solutions of $\mathbf{4}$ and $\mathbf{6 a}$ in DMSO- $\mathrm{d}_{6}$ were added to a solution of PPE $\left(6 \times 10^{-5} \mathrm{M}\right)$ in deuteriated phosphate buffer (50 mM, pD 7.5; final concentration $\left.5.10^{-4} \mathrm{M}\right) .{ }^{1} \mathrm{H}$ NMR spectra $(500 \mathrm{MHz})$ were recorded every $60 \mathrm{~min}$ during $48 \mathrm{~h}$; about $50 \%$ of 4 was hydrolyzed within $15 \mathrm{~h}$ ( $\beta$-lactam ring opening); 6a was totally hydrolyzed after $8 \mathrm{~h}$ (ester cleavage).

\subsection{Assay of porcine pancreatic elastase $e^{44}$}

To $2 \mathrm{~mL}$ of the solution of substrate (solution of $N$-succinyl-L-alanyl-L-alanyl-L-alanyl- $p$-nitroanilide $(2.7 \mathrm{mg}$ in $200 \mu \mathrm{L}$ of $N$-methyl pyrrolidone (NMP) diluted with Tris buffer $(20 \mathrm{~mL}$ at $100 \mathrm{mM}$, pH 7.5 solution)) were added $20 \mu \mathrm{L}$ of the solution of the tested compound $\left(10^{-2}-\right.$ $10^{-4} \mathrm{M}$ in NMP) and $67 \mu \mathrm{L}$ of the solution of elastase $\left(6 \times 10^{-6} \mathrm{M}\right.$ in acetate buffer $\left.(50 \mathrm{mM}, \mathrm{pH} 5)\right)$. The appearance of the substrate hydrolysis product ( $p$-nitroaniline) was measured (with a Cary 210) at $410 \mathrm{~nm}$ as a function of time.

Plots of $V / V_{\mathrm{I}}$ versus [I] (ratios of initial rates of hydrolysis in the absence and in the presence of inhibitors) gave the inhibition constants indicated in the Table 2. All experiments were performed two or three times.

The reversibility of the inhibition was controlled by the incubation/dilution method. The incubation solution consisted of $5 \mu \mathrm{L}$ of inhibitor solution $\left(10^{-3} \mathrm{M}\right.$ in DMSO), $34 \mu \mathrm{L}$ of elastase solution $\left(2.5 \times 10^{-4} \mathrm{M}\right.$ in acetate buffer, $50 \mathrm{mM}, \mathrm{pH} 5)$ and $161 \mu \mathrm{L}$ of Tris buffer $(100 \mathrm{mM}$, $\mathrm{pH} 7.5)$. At various times $(0,5,10,15,20,30 \mathrm{~min}), 10 \mu \mathrm{L}$ of the incubation solution were dissolved in $2 \mathrm{~mL}$ of the substrate solution $\left(10^{-4} \mathrm{M}\right.$ in Tris buffer), and the enzyme activity was measured as before. No decrease of activity was recorded as a function of incubation time.

\subsection{Theoretical calculations}

All the calculations have been performed at the ab initio RHF level using the minimal basis set MINI-1 ${ }^{\prime 45,46}$ They were performed with Gaussian $94^{47,48}$ on two computers, a Dec Alpha 8400 8-processor and a Dec Alpha 4100 4-processor running Digital Unix. The starting geometries were sketched drawn by standard fragments and then completely optimized following all the $3 N-6$ degrees of freedom either for the minima or the transition state structures. For each equilibrium structure, the thermochemistry data are derived from the analytical frequency calculation at $298.15 \mathrm{~K}$ and $1 \mathrm{~atm}$.

\section{References}

1. (a) Pratt, R. F. Bioorg. Med. Chem. Lett. 1992, 2, 1323. (b) Demuth, H.-V. J. Enzyme Inhibitor 1990, 3, 249. 
(c) Ator, M. A.; Ortiz de Montellano, P. R. The Enzymes, Vol. XIX; Academic: New York, 1990; pp 213-282.

2. (a) Massova, I.; Mobashery, S. Acc. Chem. Res. 1997, 30, 162. (b) Page, M. I.; Laws, A. P. Chem. Commun. 1998, 1609. (c) Matagne, A.; Dubus, A.; Galleni, M.; Frère, J.-M. Nat. Prod. Rep. 1999, 16, 1.

3. (a) Matagne, A.; Lamotte-Brasseur, J.; Frère, J.-M. Biochem. J. 1998, 330, 581. (b) Lamotte-Brasseur, J.; Knox, J.; Kelly, J. A.; Charlier, P.; Fonzé, E.; Dideberg, O.; Frère, J.-M. Biotechnol. Genetic Engng. Rev. 1994, 12, 149.

4. (a) Skiles, J. W.; Jeng, A. Y. Exp. Opin. Theor. Patents, 1999, 9, 869. (b) Balfour-Lynn, I. M. J. R. Soc. Med. 1999, 92 (Suppl. 37), 23.

5. Cregge, R. J.; Durham, S. L.; Farr, R. A.; Gallion, S. L.; Hare, C. M.; Hoffman, R. V.; Janusz, M. J.; Kim, H.-O.; Koehl, J. R.; Mehdi, S.; Metz, W. A.; Peet, N. P.; Pelton, J. P.; Schreuder, H. A.; Sunder, S.; Tardif, C. J. Med. Chem. 1998, 41, 2461.

6. Rai, R.; Katzenellenbogen, J. A. J. Med. Chem. 1992, 35, 4297.

7. Hlasta, D. J.; Court, J. J.; Desai, R. C.; Talomie, T. G.; Shen, J. A. Bioorg. Med. Chem. Lett. 1996, 6, 2941.

8. Kerrigan, J. E.; Walters, M. C.; Forrester, K. J.; Crowder, J. B.; Christopher, L. J. Bioorg. Med. Chem. Lett. 2000, 10, 27.

9. He, S.; Kuang, R.; Venkataraman, R.; Tu, J.; Truong, T. M.; Chan, H.-K.; Groutas, W. C. Bioorg. Med. Chem. 2000, 8, 1713.

10. Cabaret, D.; Garcia Gonzales, M.; Wakselman, M.; Adediran, S. A.; Pratt, R. F. Eur. J. Org. Chem. 2001, 1, 141.

11. Pochet, L.; Doucet, C.; Dive, G.; Wouters, J.; Masereel, B.; Reboux-Ravaux, M.; Pirotte, B. Bioorg. Med. Chem. 2000, 8, 1489.

12. Mascaretti, O. A.; Boschetti, C. E.; Danelon, G. O.; Mata, E. G.; Roveri, O. A. Curr. Med. Chem. 1995, 1, 441.

13. Bulychev, A.; Bellettini, J. R.; O’Brien, M.; Crocker, P. J.; Samama, J.-P.; Miller, M. J.; Mobashery, S. Tetrahedron 2000, 56, 5719.

14. Wilmouth, R. C.; Ly, Y.-H.; Wright, P. A.; Claridge, T. D. W.; Aplin, R. T.; Schofield, C. J. Tetrahedron 2000, 56, 5729.

15. Page, M. I. The Chemistry of $\beta$-lactams; Blackie Academic \& Professional: London, 1992.

16. Firestone, R. A.; Barker, P. L.; Pisano, J. M.; Ashe, B. M.; Dahlgren, M. E. Tetrahedron 1990, 46, 2255.

17. Edwards, P. D.; Bernstein, P. R. Med. Res. Rev. 1994, 14, 127.

18. Hagmann, W. K.; Kissinger, A. L.; Shah, S. K.; Finke, P. E.; Dorn, C. P.; Brause, K. A.; Ashe, B. M.; Weston, H.; Maycock, A. L.; Knight, W. B.; Dellea, P. S.; Fletcher, D. S.; Hand, K. M.; Osinga, D.; Davies, P.; Doherty, J. B. J. Med. Chem. 1993, 36, 771.

19. Green, B. G.; Chabin, R.; Mills, S.; Underwood, D. J.; Shah, S. K.; Kuo, D.; Gale, P.; Maycock, A. L.; Liesch, J.; Burgey, C. S.; Doherty, J. B.; Dorn, C. P.; Finke, P. E.; Hagmann, W. K.; Hale, J. J.; MacCoss, M.; Westler, W. M.; Knight, W. B. Biochemistry 1995, 34, 14331.

20. Vergely, I.; Laugâa, P.; Reboud-Ravaux, M. J. Mol. Graphics 1996, 14, 158.

21. Wilmouth, R. C.; Westwood, N. J.; Anderson, K.; Brownlee, W.; Claridge, T. D. W.; Clifton, I. J.; Pritchard, G. J.; Aplin, R. T.; Schofield, C. J. Biochemistry 1998, 37, 17506.

22. Clemente, A.; Domingos, A.; Grancho, A. P.; Iley, J.; Moreira, R.; Neres, J.; Palma, N.; Santana, A. B.; Valente, E. Bioorg. Med. Chem. Lett. 2001, 11, 1065.

23. Beauve, C.; Bouchet, M.; Touillaux, R.; Fastrez, J.; Marchand-Brynaert, J. Tetrahedron 1999, 55, 13301.
24. Suicide inhibitors operating via an isocyanate function created in situ are scarcely described in the literature: (a) Groutas, W. C.; Venkataraman, R.; Chong, L. S.; Yoder, J. E.; Epp, Y. J.; Stanga, M. A.; Kim, E.-H. Bioorg. Med. Chem. 1995, 3, 125. (b) Vagnoni, L. M.; Gronostaj, M.; Kerrigan, J. E. Bioorg. Med. Chem. 2001, 9, 637.

25. (a) Vigroux, A.; Bergon, M.; Bergonzi, C.; Tisnès, P. J. Am. Chem. Soc. 1994, 116, 11787. (b) Araujo, M. E. M.; Campelo, M.; Iley, J.; Norberto, F. J. Chem. Soc., Perkin Trans. 22001 , 494 and references cited therein.

26. Beauve, C.; Tjoens, G.; Touillaux, R.; Lamotte-Brasseur, J.; Marchand-Brynaert, J.; Fastrez, J. Eur. J. Org. Chem. 1999, 6, 1441 .

27. (a) Hagmann, W. K.; Shah, S. K.; Dorn, C. P.; O’Grady, L. A.; Hale, J. J.; Finke, P. E.; Thompson, K. R.; Brause, K. A.; Ashe, B. M.; Hazel, W.; Dahlgren, M. E.; Maycock, A. L.; Dellea, P. S.; Hand, K. M.; Osinga, D. G.; Bonney, R. J.; Davies, P.; Fletcher, D. S.; Doherty, J. B. Bioorg. Med. Chem. Lett. 1991, 1, 545. (b) Knight, W. B.; Chabin, R.; Green, B. Arch. Biochem. Biophys. 1992, 296, 704. (c) Knight, W. B.; Swiderek, K. M.; Sakuma, T.; Calaycay, J.; Shively, J. E.; Lee, T. D.; Covez, T. R.; Shushan, B.; Green, B. G.; Chabin, R.; Shah, S.; Mumford, R.; Dickinson, T. A.; Griffin, P. R. Biochemistry 1993, 32, 2031. (d) Westwood, N. J.; Claridge, T. D. W.; Edwards, P. N.; Schofield, C. J. Bioorg. Med. Chem. Lett. 1997, 7, 2973.

28. (a) Firestone, R. A.; Barker, P. L.; Pisano, J. M.; Ashe, B. M.; Dahlgren, M. E. Tetrahedron 1990, 46, 6585. (b) Westwood, N. J.; Schofield, C. J.; Claridge, T. D. W. J. Chem. Soc., Perkin Trans. 1 1997, 2725.

29. Salzman, T. N.; Ratcliffe, R. W.; Christensen, B. G.; Bouffard, F. A. J. Am. Chem. Soc. 1980, 120, 6161.

30. Baldwin, J. E.; Adlington, R. M.; Collins, D. W.; Schofield, C. J. Tetrahedron 1990, 46, 4733.

31. Abe, I.; Fujimoto, N.; Nishiyama, T.; Terada, K.; Nakahara, T. J. Chromatogr. A 1996, 722, 221.

32. Garcia-Alvarez, M.; Lopez-Carrasquero, F.; Tort, E.; Rodriguez-Galan, A.; Munoz-Guerra, S. Synth. Commun. 1994, 24, 745.

33. (a) Bode, W.; Meyer, E.; Powers, J. C. Biochemistry 1989, 28, 1951. (b) Odagaki, Y.; Ohmoto, K.; Matsuoka, S.; Hamanaka, N.; Nakai, H.; Toda, M.; Katsuya, Y. Bioorg. Med. Chem. 2001, 9, 647.

34. Cvetovich, R. J.; Chartrain, M.; Hartner, Jr., F. W.; Roberge, C.; Amato, J. S.; Grabowski, E. J. J. J. Org. Chem. 1996, 61, 6575.

35. Khim, S.-K.; Nuss, J. M. Tetrahedron Lett. 1999, 40, 1827 and references cited therein.

36. (a) Baldwin, J. E.; Adlington, R. M.; Godfrey, C. R. A.; Gallins, D. W.; Smith, M. L.; Russel, A. T. Synlett 1993, 51. (b) Baldwin, J. E.; Adlington, R. M.; Russel, A. T.; Smith, M. L. Tetrahedron 1995, 51, 4733.

37. Westermann, B.; Walter, A.; Diedrichs, N. Angew. Chem., Int. Ed. Engl. 1999, 38, 3384.

38. (a) Palomo, C.; Aizpurua, J. M.; Cuevas, C. J. Chem. Soc., Chem. Commun. 1994, 1957. (b) Palomo, C.; Aizpurua, J. M.; Cuevas, C.; Mielgo, A.; Galarza, R. Tetrahedron Lett. 1995, 36, 9027.

39. (a) Page, M. I.; Laws, A. P.; Slater, M. J.; Stone, J. R. Pure Appl. Chem. 1995, 67, 711. (b) Pitarch, J.; Ruiz-Lopez, M. F.; Silla, E.; Pascual-Ahuir, J.-L.; Tunon, I. J. Am. Chem. Soc. 1998, 120, 2146. (c) Pitarch, J.; Pascual-Ahuir, J.-L.; Silla, E.; Tunon, I.; Moliner, V. J. Chem. Soc., Perkin Trans. 2 1999, 1351. 
(d) Pitarch, J.; Pascual-Ahuir, J.-L.; Silla, E.; Tunon, I. J. Chem. Soc., Perkin Trans. 2 2000, 761.

40. Dive, G.; Dehareng, D. Int. J. Quant. Chem. 1999, 73, 161.

41. Dive, G.; Dehareng, D.; Peeters, D. Int. J. Quant. Chem. 1996, $58,85$.

42. Doucet, C.; Pochet, L.; Thierry, N.; Pirotte, B.; Delarge, J.; Reboud-Ravaux, M. J. Med. Chem. 1999, 42, 4161.

43. Vigneron, L.; Dive, G. unpublished result (centre d'Ingénierie des protéines, Université of Liège, Belgium); to be published.

44. (a) Baumstark, J. S.; Bardawill, W. A.; Sbarra, A. J.; Hayes, N. Biochem. Biophys. Acta 1963, 77, 676. (b) Bieth, J.; Spiess, B.; Vermuth, C. G. Biochem. Med. 1974, 11, 350.

45. Tatewaki, H.; Huzinaga, S. J. Comput. Chem. 1980, 1, 205.

46. Dive, G.; Dehareng, D.; Ghuysen, J.-M. Theor. Chim. Acta 1993, 85, 409.
47. Frisch, M. J.; Pople, J. A.; Binkley, J. S. J. Chem. Phys. 1984, $80,3265$.

48. Frisch, M. J.; Trucks, G. W.; Schlegel, H. B.; Gill, P. M. W.; Johnson, B. G.; Robb, M. A.; Cheeseman, J. R.; Keith, T.; Petersson, G. A.; Montgomery, J. A.; Raghavachari, K.; Al-Laham, M. A.; Zakrzewski, V. G.; Ortiz, J. V.; Foresman, J. B.; Cioslowski, J.; Stefanov, B. B.; Nanayakkara, A.; Challacombe, M.; Peng, C. Y.; Ayala, P. Y.; Chen, W.; Wong, M. W.; Andres, J. L.; Replogle, E. S.; Gomperts, R.; Martin, R. L.; Fox, D. J.; Binkley, J. S.; Defrees, D. J.; Baker, J.; Stewat, J. P.; Head-Gordon, M.; Gonzalez, C.; Pople, J. A. Gaussian 94 Revision E.2; Gaussian Inc.: Pittsburgh PA, 1997. 